\title{
Effect of Aphidicolin on DNA Methyltransferase in the Nucleus
}

\author{
Isao Suetake, Yasuhiko Kano, and Shoji Tajima* \\ Institute for Protein Research, Osaka University, Suita Osaka 565-0871, JAPAN
}

Key words: DNA methyltransferase/cell cycle/aphidicolin

\begin{abstract}
Methylation of cytosine in the genomic DNA plays an important role in mammalian embryogenesis. DNA methyltransferase activity, which contributes mainly to the maintenance of the methylation pattern during proliferation, is under the control of the cell cycle, its activity being higher in the $S$ phase than in the other phases (Adams, R.L.P., 1990, Biochem. J. 265, 309-320). In the present study, we examined how DNA methyltransferase is regulated in the cells arrested at $S$ phase by aphidicolin treatment. The activity and protein levels of DNA methyltransferase in the nuclei were kept constant in proliferating mouse erythroleukemia cells, and increased about twofold after $6 \mathrm{~h}$ incubation in the presence of aphidicolin. This increase of DNA methyltransferase levels by aphidicolin treatment was positively correlated with the cell population at $S$ phase. De novo synthesis of DNA methyltransferase protein was increased by the treatment. In addition, the relative half life of pulse labeled DNA methyltransferase was prolonged by aphidicolin treatment. Both increase in synthesis and prolongation of half life of DNA methyltransferase in S phase contributed to the increase of the activity and the protein levels by aphidicolin treatment. Prolongation of half life was abolished by cycloheximide, suggesting that newly synthesized protein(s) with a short half life participated in the degradation of DNA methyltransferase.
\end{abstract}

In vertebrate genome the 5 th carbon position of cytosine in the $\mathrm{CpG}$ sequence is often methylated (1). Once a pattern of DNA methylation is established, this methylated CpG pattern in genomic DNA is inherited in the progeny DNA in somatic cells. Changes in the pattern of DNA methylation is strongly correlated with such phenomena such as genomic imprinting (2), the process of X-chromosome inactivation (3) in mammals, gene expression (4), and the timing of replication (5). However, the underlying mechanisms are still unclear. When the gene encoding the DNA methyltransferase (MeTase) that catalyzes the maintenance of the methylation pattern is targeted, the genomic imprinting is abolished and the mouse cannot survive after gastrulation $(6,7)$. In addition, ectopic expression of the maintenance-type MeTase or its antisense strand in cells perturbs the cell fate (8-10). DNA methylation thus is prerequisite in vertebrates.

MeTase cDNAs of mouse, human, chicken, Xenopus laevis, and sea urchin have been isolated, and the enzyme molecules have been shown to comprise more

\footnotetext{
* To whom correspondence should be addressed.

Tel: +81-6-879-8627, Fax: +81-6-879-8629

E-mail: tajima@protein.osaka-u.ac.jp

Abbreviations: DMEM, Dulbecco's modified Eagle's medium; FCS, fetal calf serum; MEL, mouse erythroleukemia; MeTase, DNA methyltransferase; PCNA, proliferating cell nuclear antigen; SDS, sodium dodecylsulfate.
}

than 1,500 amino acid residues (11-15). The amino-terminal domain of more than 1,000 amino acid residues is thought to be a regulatory domain (16). This amino-terminal domain is connected with KG-repeat to the carboxyl-terminal domain of about 500 amino acid residues (11). The carboxyl-terminal domain is closely related to bacterial cytosine methyltransferases and is thought to be the catalytic domain. Mouse MeTase is localized to the replication foci at middle to late $\mathrm{S}$ phase, and the sequence responsible for this localization resides in the amino-terminal domain of the molecule (17). Recently, it has been demonstrated that MeTase interacts with proliferating cell nuclear antigen (PCNA) (18), an auxiliary factor for DNA replication and repair. The interaction is specific at early $\mathrm{S}$ phase and the binding is competed with the cell cycle related factor p21 ${ }^{\mathrm{WAF} 1}$, which is a cyclin-dependent kinase inhibitor. The MeTase activity changes in cell cycle-dependent manner, its activity in cells being reported to be high at $S$ phase and low at the rest of the phases when the cells at each stage are prepared by cell sorter (19). The MeTase transcript level is extremely low when the cells are in quiescent state and increases as soon as the cells start to proliferate $(20,21)$. When cells are removed from the cell cycle such as by the stimulus to differentiate or low serum conditions, MeTase mRNA and protein decrease $(22,23)$. Since the transcription activity of MeTase does not change even though the 
cells are introduced into $G_{1} / G_{0}$ phase (21-23), the down regulation of MeTase is a posttranscriptional event. The half lives of mRNA and protein become short in cells that are induced to differentiate, compared to those in proliferating cells (23). On the other hand, the production and stability of the MeTase at $\mathrm{S}$ phase is not well characterized yet.

In the present study, we aimed to examine how MeTase was regulated at $S$ phase. For this, we utilized aphidicolin, an inhibitor of DNA polymerases $\alpha, \delta$, and $\varepsilon$ (24) that arrests the cells at S phase (25). Treatment of cells with aphidicolin apparently increased the activity level and protein level of MeTase through increasing the cell populations at $\mathrm{S}$ phase, at which stage the MeTase synthesis was increased and the turnover was suppressed.

\section{MATERIALS AND METHODS}

\section{Materials}

ES medium was purchased from Nissui Seiyaku (Tokyo) and fetal calf serum (FCS) was from Gibco (Grand Island, NY). Poly $(\mathrm{dI}-\mathrm{dC}) \cdot \operatorname{poly}(\mathrm{dI}-\mathrm{dC})$ was obtained from Pharmacia (Upsala, Sweden). L-Methionine and L-cysteine free Dulbecco's modified Eagle's medium (DMEM), aphidicolin, ribonuclease A (type II-A), and cycloheximidee were purchased from Sigma (St. Louis, MO). EXPRE ${ }^{35} \mathrm{~S}^{35} \mathrm{~S}$ was from NEN (Boston, MA). The other chemicals used were of the highest reagent grade available.

\section{Cells}

Mouse erythroleukemia (MEL) 11A2 cells were kindly provided by Dr. Toshio Watanabe (Tohoku University, Sendai) (26). The cells were maintained in ES medium supplemented with $2 \%$ FCS. Cell proliferation was arrested by treating the cells with $2.5 \mu \mathrm{g} / \mathrm{ml}$ of aphidicolin.

\section{Flow cytofluorometric analysis}

The cells were fixed and stained with propidium iodine as described by Crissman et al. (27), with a slight modification as follows. The fixed cells were treated with ribonuclease $\mathrm{A}$ at $37^{\circ} \mathrm{C}$ for $14 \mathrm{~h}$. The stained cells were analyzed by flow cytofluorometry using a cell sorter, model Cyto ACE-300 (JASCO Co., Tokyo).

\section{MeTase activity}

The nuclear extract was prepared according to the method described by Bestor and Ingram (28) and was used as the source of the enzyme. The MeTase activity was determined as described by Takagi et al. (10) using poly $(\mathrm{dI}-\mathrm{dC}) \cdot \operatorname{poly}(\mathrm{dI}-\mathrm{dC})$ as a substrate.

\section{Western blot analysis and immunoprecipitation of MeTase} For Western blot analysis, the nuclear extract was electrophoresed in 7\% sodium dodecylsulfate (SDS)-polyacrylamide gel and the protein bands were electrophoretically blotted onto nylon membranes (GeneScreen, NEN, Boston, MA). The MeTase protein bands were immunodetected as described by Takagi et al. (10), using immunoselected anti-MeTase antibodies as the first antibodies and ${ }^{125}$ I-labeled protein A for detecting the MeTase-antibodies complex. The radioactivities of MeTase bands were determined in a $\gamma$-well type scintillation counter, model ARC-370 (Aloka, Co., Ltd., Tokyo)

For immunoprecipitation, cells were cultivted for $2 \mathrm{~h}$ in $1 \mathrm{ml}$ of L-methionine and L-cysteine free DMEM with EXPRE ${ }^{35} \mathrm{~S}^{35} \mathrm{~S}$ containing $\left.{ }^{35} \mathrm{~S}\right]-\mathrm{L}$-methionine $(5 \mu \mathrm{Ci}$ per $1 \times$ $10^{6}$ cells), supplemented with $2 \%$ FCS, which had been extensively dialyzed against Dulbecco's phosphate buffered saline. The radiolabeled MeTase was immunoprecipitated as described by Takagi et al. (10) with a slight modification as follows. To denature the nuclear protein, SDS was added to 75 $\mu \mathrm{l}$ of the nuclear extract at the final concentration of $4.5 \%$ and boiled for $2 \mathrm{~min}$. The mixture was diluted with a $1 \mathrm{ml}$ aliquot of solution containing $0.1 \mathrm{M} \mathrm{NaCl}, 2 \mathrm{mM}$ EDTA, $2 \%$ Triton X-100, $5 \mathrm{mM}$ iodoacetamide, $0.75 \mathrm{u} / \mathrm{ml}$ Trasylol, and $50 \mathrm{mM}$ triethanolamine $(\mathrm{pH} 7.5)$, and the mixture was then incubated with the first antibodies as described by Takagi $e t$ al. (10).

\section{Other methods}

To determine DNA content in each nuclear suspension, genomic DNA was isolated from a portion of the cell suspension and its concentration was determined spectrophotometrically as described (29). Ribonuclease A that was free of deoxyribonuclease was obtained as described (29). The radioactivities of the $\left[{ }^{35} \mathrm{~S}\right]$-labeled MeTase protein bands were determined with an image analyzer, BAS 2000 (Fuji Photo Film Co., Ltd.)

\section{RESULTS}

Treatment of cells with aphidicolin inhibits the activities of DNA polymerases $\alpha, \delta$ and $\varepsilon$ and arrests the cells at $S$ phase $(24,25)$. Exponentially increasing DNA in proliferating MEL cells was almost completely inhibited in the presence of $2.5 \mu \mathrm{g} / \mathrm{ml}$ of aphidicolin (Fig. 1). When cells were incubated with aphidicolin, the cell populations containing $4 \mathrm{n}$ decreased, and the front peak that contained the $2 \mathrm{n}$ populations (channel 68) in proliferating cells were broadened and shifted toward 4n (panels B-D). After aphidicolin treatment, the cells at the front peak were not at $G_{1}$ phase but were arrested at early $\mathrm{S}$ phase (25). The profiles of flow cytofluorometry after $6 \mathrm{~h}$ incubation with aphidicolin showed almost no $4 \mathrm{n}$ populations and the front peak shifted 2 channels toward 4n (channel 70) compared with the proliferating cells (panel C). That is, most of the cells at $\mathrm{G}_{2} / \mathrm{M} / \mathrm{G}_{1}$ entered $\mathrm{S}$ phase after $6 \mathrm{~h}$ incubation in the presence of aphidicolin. This coincides with the fact that the S-phase population ( $>2 n$ and $<4 n$ ) of the pro- 


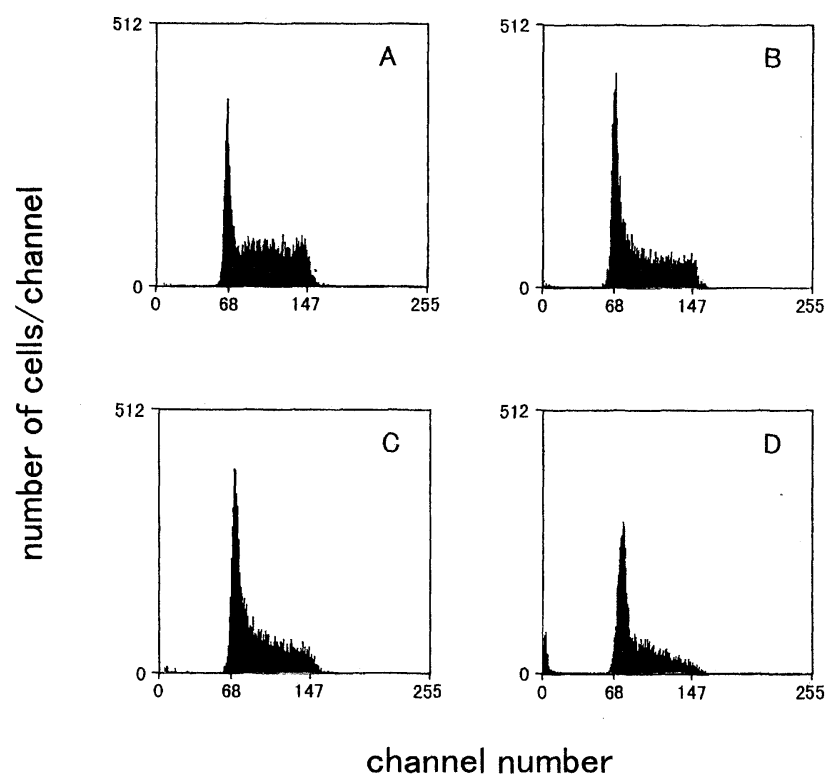

Fig. 1. Flow cytofluorometry of MEL cells. Proliferating cells (A) were incubated with $2.5 \mu \mathrm{g} / \mathrm{ml}$ aphidicolin for $4 \mathrm{~h}(\mathrm{~B}), 6 \mathrm{~h}(\mathrm{C})$, and 15 $h$ (D). After the incubation the cells were fixed and stained with propidium iodine and analyzed by a cell sorter as described in the 'Materials and Methods'. The positions of channel 68 and 147 indicate the DNA contents of $2 \mathrm{n}$ and $4 \mathrm{n}$ per cell, respectively.

liferating cells was calculated to be about $60 \%$ (panel A) and the doubling time of the MEL 11A2 cells were about $14 \mathrm{~h}$.
The effect of aphidicolin treatment on MeTase activity was determined. MeTase activity in nuclei normalized with the DNA content of MEL cells under growth conditions in the absence of aphidicolin remained constant. In contrast, the activity increased about twofold after $6 \mathrm{~h}$ incubation and the increased activity then remained at similar levels for $23 \mathrm{~h}$ in the presence of aphidicolin (Fig. 2A).

The nuclear extracts of cells treated with or without aphidicolin were electrophoresed in SDS-polyacrylamide gel and their MeTase bands were immunodetected (Fig. 2B). The amounts of MeTase were normalized to the DNA content of cells (Fig. 2C). Similar to the enzyme activities, MeTase protein levels in nuclei remained roughly constant in proliferating MEL cells. In contrast, MeTase protein increased about twofold in cells incubated for $6 \mathrm{~h}$ in the presence of aphidicolin. This change in MeTase protein levels was similar to that of MeTase activities under corresponding conditions.

Aphidicolin treatment apparently increased MeTase activity and protein levels about twofold after $6 \mathrm{~h}$ incubation (Fig. 2). The increase of MeTase activity level and protein level by aphidicolin treatment could be due to the increased populations of MEL cells in S phase.

To evaluate the production rate of MeTase, the cells were preincubated for $4 \mathrm{~h}$ either in growth medium or in medium containing aphidicolin, and the media were then replaced with those supplemented with $\left[{ }^{35} \mathrm{~S}\right]-\mathrm{L}-$ methionine and $\left.{ }^{35} \mathrm{~S}\right]-\mathrm{L}$-cysteine, and incubated for an additional $2 \mathrm{~h}$. The radiolabeled MeTase in the nuclei
A

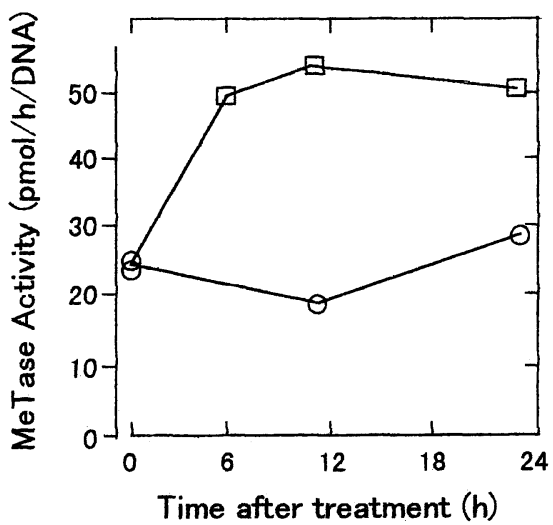

B

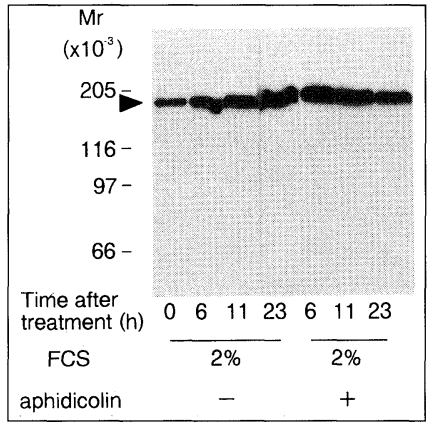

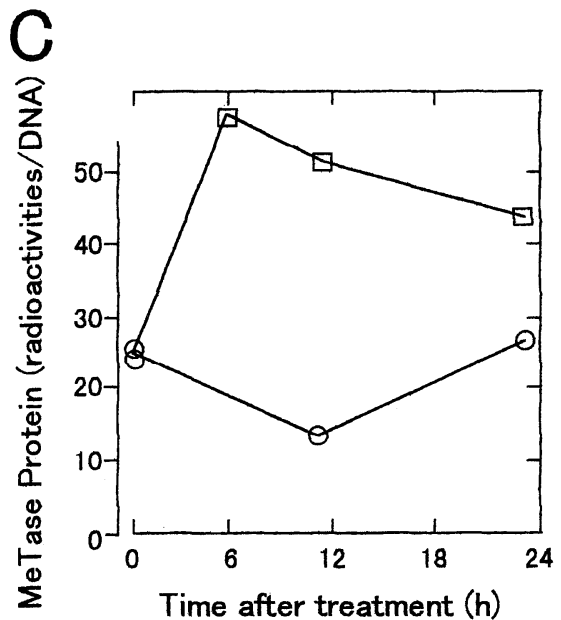

Fig. 2. Effect of aphidicolin on the MeTase. Proliferating MEL cells $\left(2 \times 10^{6}\right.$ cells per dish) were washed with phosphate buffered saline (time 0$)$ and then cultivated in $10 \mathrm{ml}$ of ES medium containing $2 \%$ FCS $(\bigcirc)$ or $2 \%$ FCS plus $2.5 \mu \mathrm{g} / \mathrm{ml}$ aphidicolin $(\square)$. At the indicated time, the cells were harvested. A. The MeTase activities were determined and normalized with genomic DNA content as shown. B. Western blot. The cells were treated as described in (A). The nuclear extract was electrophoresed, and the bands of MeTase were immunodetected. For the immunodetection of the MeTase shown in the lane of the $23 \mathrm{~h}$ incubation under growth conditions, half as much nuclear extract as that of the time 0,6 , or 11 $\mathrm{h}$ incubation was loaded to the gel electrophoresis. The arrowhead indicates the MeTase bands. The positions of molecular weight (Mr) markers are indicated. C. The protein content of the MeTase. The radioactivities of the bands in (B) were measured, and the values normalized with genomic DNA content (per $\mu \mathrm{g}$ ) are shown. 

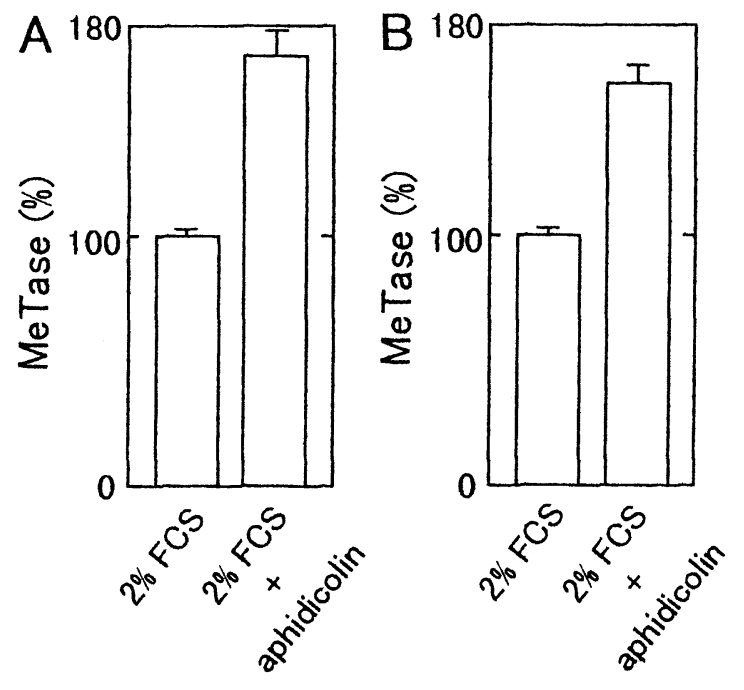

Fig. 3. Effect of aphidicolin on the production (A) and stabilization of the MeTase (B). A. Proliferating MEL cells $\left(1 \times 10^{6}\right.$ cells per dish) were incubated for $4 \mathrm{~h}$ in $1 \mathrm{ml}$ of ES medium containing $2 \%$ FCS, or $2 \%$ FCS plus $2.5 \mu \mathrm{g} / \mathrm{ml}$ aphidicolin. The cells were then incubated for another $2 \mathrm{~h}$ in $1 \mathrm{ml}$ of L-methionine and L-cysteine free DMEM supplemented with EXPRE ${ }^{35} \mathrm{~S}^{35} \mathrm{~S}$, added with $2 \% \mathrm{FCS}$, or $2 \%$ FCS plus $2.5 \mu \mathrm{g} / \mathrm{ml}$ aphidicolin. The MeTase in isolated nuclei was immunoprecipitated, electrophoresed, and then its radioactivities were determined. The radioactivities of the MeTase were normalized with the genomic DNA content. The average value of the MeTase in the cells cultivated in the presence of $2 \%$ FCS was taken as $100 \%$. The values obtained from 9 different dishes from three independent experiments were $100 \pm 3.0$ and $167 \pm 11.2$ (average \pm SEM) for the cells incubated in the medium containing $2 \%$ FCS and $2 \%$ FCS plus $2.5 \mu \mathrm{g} / \mathrm{ml}$ aphidicolin. B. Proliferating MEL cells $\left(1 \times 10^{6}\right.$ per dish $)$ were radiolabeled for $2 \mathrm{~h}$, and then incubated for another $6 \mathrm{~h}$ in the ES medium containing $2 \%$ FCS, or $2 \%$ FCS plus $2.5 \mu \mathrm{g} / \mathrm{ml}$ aphidicolin. After incubation the MeTase was immunoprecipitated and determined. The radioactivities of the MeTase was normalized with the genomic DNA content. The average value of MeTase that remained after the chase under the growth condition was taken as $100 \%$. The values obtained in 6 different dishes from two independent experiments were $100 \pm 4.0$ and $157 \pm 7.7$ (average \pm SEM) for the cells incubated in the medium containing $2 \%$ FCS and $2 \%$ FCS plus $2.5 \mu \mathrm{g}$ $/ \mathrm{ml}$ aphidicolin, respectively.

was extracted, immunoprecipitated, and electrophoresed in SDS-polyacrylamide gel, and the radioactivities of the MeTase bands were determined and normalized with DNA content. The amount of MeTase newly produced in the nuclei of the cells treated with aphidicolin was about 1.7 -fold greater than that of the cells cultivated under growth conditions (Fig. 3A). The result suggests that the aphidicolin treatment increased the production of MeTase.

The turnover rate of MeTase in the nuclei was estimated. Cells were pulse labeled and then chased for $6 \mathrm{~h}$ either in the growth medium or in the medium containing aphidicolin, and MeTase in the nuclei was immunodetected (Fig. 3B). The content of MeTase after $6 \mathrm{~h}$ in-

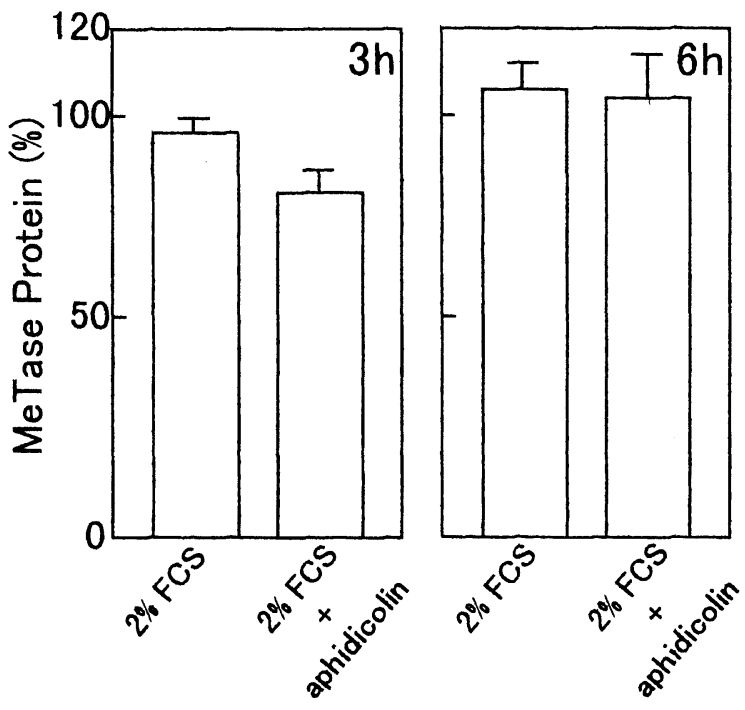

Fig. 4. Effects of cycloheximide on the MeTase turnover. Proliferating MEL cells $\left(1 \times 10^{6}\right.$ per dish) were incubated for $3 \mathrm{~h}$ or $6 \mathrm{~h}$ in ES medium containing $2 \%$ FCS, or $2 \%$ FCS plus $2.5 \mu \mathrm{g} / \mathrm{ml}$ aphidicolin in the presence of $1 \mathrm{mM}$ cycloheximide. The nuclear extract was perpared and the MeTase was determined by Western blot analysis. The radioactivities of the bands were normalized with the genomic DNA content. The average value of that obtained from the cells prior to the cycloheximide treatment (at time 0 ) was taken as $100 \%$. The values obtained from three independent experiments were $95 \pm 3.0$ and $82 \pm 5.8(3 \mathrm{~h})$, and $107 \pm 5.9$ and $104 \pm 9.8(6 \mathrm{~h})$ (average \pm SEM), under the growth condition and in the presence of aphidicolin, respectively.

cubation in the presence of aphidicolin was about 1.6fold greater than that cultivated in the growth medium. This result indicates that the prolongation of turnover rate of MeTase at $\mathrm{S}$ phase contributed to the high levels of activity and protein content of MeTase observed in Fig. 2.

Addition of cycloheximide, an inhibitor of protein synthesis, to the medium abolished the effect of aphidicolin on the turnover rate of MeTase (Fig. 4). The concentration of cycloheximide used in the present study inhibited about $97 \%$ of the total protein synthesis in MEL cells. The results indicate that the turnover process of MeTase is under the control of de novo protein synthesis.

\section{DISCUSSION}

The transcript level and the protein level of MeTase are under the control of the cell cycle (21-23). Induction of cell differentiation $(22,23)$ or suppression of cell proliferation by low serum condition (21) decreases the transcript level without affecting transcription activity. In addition, the half lives of MeTase mRNA and protein are shortened by the induction of cell differentiation (23). However, the regulation of MeTase at S phase, 
especially at the protein level, has not been characterized. It is reported that MeTase activity is high at $\mathrm{S}$ phase and low at $G_{1}$ phase by measuring the activity of the cells at each stage isolated with cell sorter (19). Although the cell sorter effectively isolates cells at a specific stage, is cannot be utilized to evaluate the stability or production of MeTase at S phase. The cells isolated by cell sorter, which cannot be arrested at a specific stage, continuously proceed into the next $\mathrm{G}_{2}$ phase under growth condition. Therefore, it is necessary to utilize certain reagents or treatments to better characterize the production rate or the stability of the MeTase at S phase.

In the present work, we utilized aphidicolin, a tetracyclic diterpenoid antibiotic that inhibits replicative eucaryotic DNA polymerases $\alpha, \delta$ and $\varepsilon$ (24), as a reagent to examine the properties of MeTase at $\mathrm{S}$ phase. As shown in Fig. 2, treatment of the cells with aphidicolin, which arrests the cells at S phase (Fig. 1), apparently increased the MeTase activity and protein levels, suggesting that the cell differentiation- and the low serum condition-dependent down regulation of MeTase is not just due to the arrest of cell cycle but to the stage-dependent arrest of the cell cycle. Aphidicolin-dependent increase in MeTase clearly indicates that some mechanisms exist that regulate the MeTase in posttranscriptional steps.

This apparent increase in MeTase by aphidicolin treatment was expected as a result of the increase in cell population at $\mathrm{S}$ phase, as the activity is reported to be high in S phase when cells are prepared using cell sorter (19). Since the percentage of MEL cells at $S$ phase during proliferation was about $60 \%$ (Fig. 1A) and the doubling time of cells was about $14 \mathrm{~h}$, a $6 \mathrm{~h}$-treatment of cells with aphidicolin makes almost all the cells enter $\mathrm{S}$ phase. In good agreement with this, MeTase activity and protein reached almost the maximal level after $6 \mathrm{~h}$ incubation with aphidicolin (Fig. 2). In addition, the increased MeTase in aphidicolin-treated MEL cells that were $100 \%$ at $\mathrm{S}$ phase was maintained at a level twice that in proliferating cells that were $60 \%$ in S phase. The result suggests that very low levels of MeTase exist at the other cell cycle phases other than S phase. This is consistent with the result reported by Adams (19).

The change in the steady-state level of MeTase protein caused by aphidicolin treatment should be determined by its synthesis and degradation. Firstly, we have tested the effect of aphidicolin on the production activity of MeTase in MEL cells. As shown in Fig. 3A, the production of MeTase in the cells treated with aphidicolin after a short incubation period was 1.7 -fold higher than that in proliferating cells. Therefore, the increase of de novo synthesis may contribute to the increase of MeTase by aphidicolin treatment shown in Fig. 3A. The half life of MeTase protein was signifi- cantly longer in cells treated with aphidicolin than that of proliferating cells (Fig. 3B). Thus, it can be concluded that the increase of MeTase protein on aphidicolin treatment is caused by both promotion of synthesis and prolongation of half life of MeTase protein.

Although the mechanisms of the prolongation of the half life of the MeTase protein in the MEL cells treated with aphidicolin remain to be clarified, the interaction with other proteins, such as PCNA (18), or the localization of the protein at replication foci at late S phase (17), may offer clues to explain the phenomena, i.e., binding or localization of the protein at specific sites may make it more susceptible to the proteases that degrade the protein. As the rhythm of the cell cycle is restored as soon as aphidicolin is removed from the culture medium (25), it is unlikely that aphidicolin directly affected the half life of MeTase, hence the effect of aphidicolin on the turnover rate of MeTase would seem to be rather indirect. The $\mathrm{S}$ phase arrest may be the cause for the synthesis and prolongation of the half life of the protein.

Cycloheximide treatment of cells abolished the effect of aphidicolin on the turnover rate of MeTase. This indicates that newly synthesized protein(s) may participate in the MeTase turnover in a cell cycle dependent manner. As the effect of cycloheximide was observed within $3 \mathrm{~h}$ (Fig. 4A), this would suggest that the half life of this unknown protein(s) may be very short.

Acknowledgements. We wish to thank Dr. Yasuko Miyake (National Cardiovascular Center Research Institute, Osaka, Japan) for critical reading of the manuscript. This work was supported by Grantsin-Aid for The Joint Research between Institute for Protein Research and Institute of Scientific and Industrial Research, Osaka University, from the Ministry of Education, Science, Sports and Culture of Japan, and the Naito Foundation. IS is the recipient of a postdoctoral fellowship from the Japan Society for the Promotion of Science.

\section{REFERENCES}

1. RAZIN, A. and SzYF, M. 1984. DNA methylation patterns. Biochim. Biophys. Acta., 782: 331-342.

2. RASIN, A. and CEDAR, H. 1994. DNA methylation and genomic imprinting. Cell, 77: 473-476.

3. MigeON, B.R. 1994. X-chromosome inactivation: molecular mechanisms and genetic consequences. Trends in Genet., 10: 230-235.

4. EDEN, S. and CEDAR, H. 1994. Role of DNA methylation in the regulation of transcription. Curr. Opin Genet. and Dev., 4: $255-259$.

5. Serlig, S., Ariel, M., Goitein, R., Marcus, M., and Cedar, H. 1988. Regulation of mouse satellite DNA replication time. ЕМВО J., 7: 419-426.

6. Li, E., BeStOR, T.H., and JAENISCH, R. 1992. Targeted mutation of the DNA methyltransferase gene results in embryonic lethality. Cell, 69: 915-926.

7. Li, E., BeARD, C., and JAENisch, R. 1993. Role for DNA 
methylation in genomic imprinting. Nature, 366: 362-365.

8. TAYloR, S.M. and Jones, P.A. 1979. Multiple new phenotypes induced in 10T1/2 and 3T3 cells treated with 5-azacytidine. Cell, 17: 771-779.

9. SzyF, M., Rouleau, J., Theberge, J., and Bozovic, V. 1992. Induction of myogenic differentiation by an expression vector encoding the DNA methyltransferase cDNA sequence in the antisense orientation. J. Biol. Chem., 267: 12831-12836.

10. TaKagi, H., Tajima, S., and Asano, A. 1995. Overexpression of DNA methyltransferase in myoblast cells accelerates myotube formation. Eur. J. Biochem., 231: 282-291.

11. Bestor, T., Laudano, A., Mattaliano, R., and Ingram, V. 1988. Cloning and sequencing of a cDNA encoding DNA methyltransferase of mouse cells. J. Mol. Biol., 203: 971-983.

12. Yen, R.-W.C., Vertino, P.M., Nelkin, B.D., Yu, J.J., ElDeiry, W., Cumaraswamy, A., Lennon, G.G., Trask, B.J., Celano, P., and Baylin, S.B. 1992. Isolation and characterization of the cDNA encoding human DNA methyltransferase. Nucl. Acids Res., 20: 2287-2291.

13. Tajima, S., Tsuda, H., WaKabayashi, N., Asano, A., Mizuno, S., and NishimoRI, K. 1995. Isolation and expression of a chicken DNA methyltransferase cDNA. J. Biochem., 117: 1050-1057.

14. Kimura, H., Ishihara, G., and TaJima, S. 1996. Isolation and expression of Xenopus laevis DNA methyltransferase cDNA. $J$. Biochem., 120: 1182-1189.

15. Aniello, F., Locascio, A., Fucci, L., Geraci, G., and BRANNO, M. 1995. Isolation of cDNA clones encoding DNA methyltransferase of sea urchin $P$. lividus. Expression during embryonic development. (EMBL database, accession No.Z50183)

16. BestoR, T.H. 1992. Activation of mammalian DNA methyltransferase by cleavage of a $\mathrm{Zn}$ binding regulatory domain. EMBO J., 11: 2611-2617.

17. Leonhardt, H., Page, A.W., Weier, H.-U., and Bestor, T.H. 1992. A targeting sequence directs DNA methyltransferase to sites of DNA replication in mammalian nuclei. Cell, 71: 865-873.

18. Chuang, L.S.-H., IAN, H.-I., КoH, T.-W., NG, H.-H., Xu, G., and LI, B.F.L. 1997. Human DNA-(cytosine-5) methyltransferase-PCNA complex as a target for p21 ${ }^{\mathrm{WAF} 1}$. Science, 277: 1996-2000.
19. Adams, R.L.P. 1990. DNA methylation. Biochem. J., 265: 309-320.

20. Szyf, M., Kaplan, F., Mann, V., Giloh, H., Kedar, E., and RAZIN, A. 1985. Cell cycle-dependent regulation of eukaryotic DNA methyltransferase level. J. Biol. Chem., 260: 8653-8658.

21. SzyF, M., Bozovic, V., and Tanigawa, G. 1991. Growth regulation of mouse DNA methyltransferase gene expression. $J$. Biol. Chem., 266: 10027-10030.

22. Liu, Y., Sun, L., and Jost, J.P. 1996. In differentiating mouse myoblasts DNA methyltransferase is posttranscriptionally and posttranslationally regulated. Nucl. Acids Res., 24: 2718-2722.

23. Teubner, B. and Schulz, W.A. 1995. Regulation of DNA methyltransferase during differentiation of F9 mouse embryonic carcinoma cells. J. Cell Physiol., 165: 284-290.

24. HÜBSCHER, U. and SPADARI, S. 1994. DNA replication and chemotherapy. Physiol. Rev., 74: 259-304.

25. Pedrali-Noy, G., Spadari, S., Miller-Faures, A., Miller, A.O.A., KRUPPA, J., and КосH, G. 1980. Synchronization of HeLa cell cultures by inhibition of DNA polymerase $\alpha$ with aphidicolin. Nucl. Acids Res., 8: 377-387.

26. Watanabe, T., and Oishi, M. 1987. Dimethyl sulfoxide-inducible cytoplasmic factor involved in erythroid differentiation in mouse erythroleukemia (Friend) cells. Proc. Natl. Acad. Sci. USA., 84: 6481-6485.

27. Crissman, H.A. and Steinkamp, J.A. 1973. Rapid, simultaneous measurement of DNA, protein, and cell volume in single cells from large mammalian cell populations. J. Cell Biol., 59: 766-771.

28. BeStor, T.H. and InGRAM, V.M. 1985. Growth-dependent expression of multiple species of DNA methyltransferase in murine erythroleukemia cells. Proc. Natl. Acad. Sci. USA., 82: 2674-2678.

29. Sambrook, J., Fritsch, E., and Maniatis, T. 1989. Molecular cloning: A laboratory manual, 2nd ed., Cold Spring Harbor Laboratory Press, Cold Spring Harbor, NY.

(Received for publication, April 2, 1998 and accepted, April 23, 1998) 